\title{
Kinerja Keuangan Ditinjau Dari Leverage, Likuiditas, Ukuran Perusahaan, Dewan Komisaris Independen, Dan Komite Audit
}

\author{
Masna Rina Fitriyati*, Kartika Hendra Titisari, Yuli Chomsatu Samrotun \\ Universitas Islam Batik Surakarta, JL. KH. Agus Salim No. 10, Jawa Tengah, Indonesia \\ "Correspondence e-mail: masnarina16@gmail.com
}

\begin{abstract}
Abstrak. Penelitian ini bertujuan untuk menguji serta menganalisis pengaruh leverage, likuiditas, ukuran perusahaan, dewan komisaris independen, serta komite audit terhadap kinerja keuangan. Data dalam penelitian berupa laporan keuangan. Populasi pada perusahaan LQ-45 terdaftar di Bursa Efek Indonesia dari tahun 2017-2019. Sampel penelitian menggunakan purposive sampling sehingga diperoleh 27 perusahaan yang memenuhi kriteria. Metode analisis menggunakan regresi linear berganda. Hasil analisis menjelaskan levarege, likuiditas serta dewan komisaris independen mempengaruhi kinerja keuangan. sebaliknya ukuran perusahaan serta komite audit tidak mempengaruhi kineja keuangan. Hasil riset Adjusted $r$ square sebesar 54.3\% menjelaskan leverage, likuiditas, ukuran perusahaan, dewan komisaris independen serta komite audit dapat menerangkan varaiabel kinerja keuangan. riset ini bisa digunakan pada perusahaan buat tingkatan kinrja keuangan.
\end{abstract}

Kata kunci : leverage; likuiditas; ukuran perusahaan; tata kelola perusahaa; kinerja keuangan

\begin{abstract}
This study aims to examine and analyze the effect of leverage, liquidity, company size, independent board of commissioners and audit committee on financial perfomance. The data used in this study are secondary data ini the form of financial statements. The population in this study is LQ-45 companies listed on the Indonesia Stock Exchange in 2017-2019. Samples were selected from the purposive sampling method and 27 samples were obtained based on several criteria. The analysis technique used in this study is multiple linear regression analysis. The analysis shows that leverage, liquidity, independent commissioner influence of the financial perfomance. While the company size and audit committee has no effect on the financial perfomance. Simultaneously leverage, liquidity,company size, independent commissioner and audit committee were able to explain the dependent variable that is the financial perfomance by $54.3 \%$ and the rest was influenced by other variables. This research can be used by companies to increase the financial perfomance of the company.
\end{abstract}

Keywords: leverage; liquidity; company size; corporate governance; financial perfomance

\section{PENDAHULUAN}

Situasi ekonomi saat ini mengakibatkan tingginya daya saing antar satu perusahaan dengan perusahaan lainnya. Daya saing yang begitu ketat memungkinkan perusahaan yang ada dapaat meningkatkan kualitas dan kinerja keuangan, sehingga mencapai tujuan perusahaan. Karena perusahaan sangat kompetitif, maka perusahaan harus bersaing untuk menarik para investor agar menanamkan modalnya di perusahaanya. Kinerja keuangan menjadi salah satu bentuk prestasi perusahaan yang mencerminkan tingkat laba yang diperoleh suatu perusahaan (Sari et al, 2020). Data keuangan dapat dilihat sebagai penentu baik tidaknya kinerja keuangan. Data keuangan diperoleh dari laporan keuangan. Informasi yang cepat serta berkelanjutan yang diberikan dalam bentuk informasi akuntansi berupa laporan keuangan dapat membantu perusahaan menentukan status dan kinerja ekonomi perusahaan. Mengevaluasi kinerja keuangan perusahaan dapat dilakukan dengan menganalisis laporan keuangan perusaahaan. Analisis rasio dibedakan menjadi banyak jenis, antara lain rasio likuiditas, rasio aktivitas, rasio solvabilitas serta rasio profitabilitas (keuntungan).

leverage yang dihasilkan perusahaan memeprngaruhi kinerja keuangan. leverage dapat diartikan sebagai tinggi rendahnya resiko yang terlibat dalam perusahaan. Leverage perlu dikelola dengan tepat, karena terlalu banyak hutang dapat mempengaruhi kinerj akeuangan. Penelitian Sari et al. (2020) menunjukkan leverage mempengaruhi kinerja keuangan, dan penelitian Putri \& Dermawan, (2020) menemukan leverage tidak mempengaruhi kinerja keuangan.

likuiditas mencerminkan kemampuan perusahaan dalam membayar hutang jangka pendek. Tasmil et al. (2019) menunjukkan likuiditas berpengaruh terhadap kinerja keuangan, sedangkan Anthonie et al. (2018) likuiditas tidak berpengaruh terhadap kinerja keuangan.

Salah satu faktor penentu status keuangan perusahaan adalah ukuran perusahaan. Besar kecilnya perusahaan terbagi menjadi 3(tiga) bagian yaitu perusahaan kecil, perusahaan menengah danperusahaan besar. Perusahaan yang lebih besar akan berdampak signifikan terhadap labaperusahaan. Peneliti Peneliti Shibutse et al. (2019) dan Mwangi (2018) menunjukkan ukuran perusahaan mempengaruhi kinerja keuangan, sedangkan penelitian Eyigege (2018) menunjukkan ukuran perusahaan tidak mempengaruhi kinerja keuangan.

Aspek tata kelola perusahaan, seperti komisaris independen dan komite audit, mempunyai pengaruh pada manajemen perusahaan. Susunan Dewan komisaris merupakan salah satu ciri direksi yang berkaitan dengan 
isi informasi akuntansi. Tanggung jaawab komite audit adalah untuk memastikan bahwa operasis harian sesuai dengan kebijakan perusahaan dan laporan keuangan yang disampaiakn sesuai dengan standar akuntansi keuangan yang berlaku umum. Dengan dibentuknya komite audit diharapkan dapat memperkuat pengandalian internal perusahaan dan mampu memperlihatkan pemegang saham. Penelitian Corrina (2018) menjelaskan dewan komisaris independen dan komite audit mempengaruhi kinerja keuangan, sedangkan penelitian Aiman \& Rahayu (2019) menemukan dewan komisaris independen tidak mempengaruhi kinerja keuangan.

Penelitian ini dilakukan pada perusahaan LQ-45 dan periode peneltian yaitu 2017-2019. Bertentangan dengan hasil penelitian sebelumnya, penelitian ini dapat mengkaji kembali leverage, likuiditas, ukuran perusahaan, dewan komisaris independen, dan komite audit.

\section{Tinjauan Pustaka}

Pengaruh leverage dari debt to equity ratio menunjukkan bahwa ekuitas perusahaan dapat melunasi hutangnya dan mengevaluasi sejauh mana kegiatan bisnis perusahaan melalui hutang. Jika leverage dapat diguankan dengan baik, leverage dapat mendatangkan keuntungan bagi perusahaan daripada menggunakan ekuitas perusahaan. Rasio hutang terhadap ekuitas yang lebih tinggi dapat menunjukkan apakah perusahaan perusahaan dapat beroperasi dengan hutang sebagai ekuitas. Penelitian oleh Sari et al. (2020), Aiman \& Rahayu (2019),serta Kajola et al. (2019) Hasil penelitian menunjukkan leverage mempengaruhi kinerja keuangan. Hipotesis pertama adalah sebagai berikut:

$\mathrm{H1}$ : Leverage mempengaruhi kinerja keuangan.

Likuiditas dapat diartikan sebagai kesanggupan perusahaan dalam melunasi hutang jangka pendek dalam jumlah yang besar (biasanya kurang dari satu tahun). Curent ratio dapat digunakan untuk merumuskan rasio likuiditas. Rasio lancar dihitung dengan memperhatikan kemmapuan aset lancar untuk membayar hutang lancar (hutang), yang berati tingkat likuiditas akan berubah. Jika current ratio perusahaan tinggi makan return on asset perusahaan akan sangat rendah yang akan berdampak pad aprofitabilitas perusahaan. Anthonie et al. (2018) menyatakan likuiditas mempengaruhi kinerja keuangan. Penelitian Azzahra \& Nasib (2019) juga menunjukkan likuiditas mempengaruhi kinerja keuangan. Hipotesis kedua adalah sebagai berikut:

$\mathrm{H} 2$ : Likuiditas mempengaruhi kinerja keuangan.

Ukuran perusahaan menunjukkan besarnya perusahaan. Menurut Sartono (2010) perusahaan besar dengan kondisi yang baik jauh lebih mudah mendapatkan modal di pasar modal dibandingkan perusahaan kecil. Penelitian Maryadi \& Darmawan
(2019) dan Shibutsea et al. (2019). Hasil penelitian menunjukkan ukuran perusahaan mempengaruhi kinerja keuangan. Hipotesis ketiga adalah sebagai berikut:

H3: Ukuran perusahaan mempengaruhi kinerja keuangan.

Menurut Fahmi (2014:10), dewan komisaris diangkat karena faktor pengetahuan dan pengalaman di lapangan sudah diakui dan kemampuan memberikan pendapat kepada ketua dewan komisaris dalam setiap keputusan, terutama keputusan yang diambil oleh manajemen perusahaan. Penelitian oleh Corrina (2018) dan Fuad (2018) menunjukkan dewan komisaris independen mempengaruhi kinerja keuangan. Hipotesis keempat adalah sebagai berikut:

H4: Dewan komisaris independen mempengaruhi kinerja keuangan.

Komite Audit memiliki tugas mengawasi jalannya laporan keuangan, memantau audit eksternal, serta kepatuhan terhadap sistem pengendalian internal (termasuk audit internal). Penelitian Sari et al. (2020) dan Corrina (2018) menunjukkan komite audit mempengaruhi kinerja keuangan. Hipotesis kelima adalah sebagai berikut:

H5: komite aduit mempengaruhi kinerja keuangan.

\section{METODE}

Jenis penelitian ini adalah penelitian kuantitatif. Penelitian ini menggunakan varaiabel leverage (X1), likuiditas (X2), ukuran perusahaan (X3), dewan komisaris independen (X4), serta komite audit (X5). Sumber data untuk penelitian ini adalah laporan keuangan dan tahunan perusahaan LQ-45 tahun 20172019. Alat analisis menggunakan regresi linear berganda.

\section{HASIL DAN PEMBAHASAN}

Penelitian ini bertujuan untuk mengetahui serta menganalisa pengaruh leverage, likuiditas, ukuran perusahaan, komisaris independen serta komite audit terhadap kinerja keuangan perusahaan LQ-45 yang terdaftar di Bursa Efek Indonesia tahun 2017-2019. Teknik yang digunakan dalam penelitian adalah teknik purposive sampling sehingga diperoleh sampel sebanyak 27 perusahaan, tabel berikut menggambarkan contoh penelitian ini:

Tabel 1. Pemilihan Sampel

\begin{tabular}{llc}
\hline \multicolumn{1}{c}{ Keterangan } & Jumlah \\
\hline 1. Seluruh perusahaan LQ-45 yang tercatat di & \\
BEI dari tahun 2017-2019 & 45 \\
2. Perusahaan mengalami delesting selama tahun & \\
2017-2019 & (14) \\
3. Perusahaan yang laporan keuangannya tidak & (0) \\
lengkap & Perusahaan yang tidak menggunakan mata
\end{tabular}


Masna Rina Fitriyati, Kartika Hendra Titisari dan Yuli Chomsatu Samrotun, Kinerja Keuangan Ditinjau Dari Leverage, Likuiditas, Ukuran Perusahaan, Dewan Komisaris Independen, Dan Komite Audit

uang rupiah

Perusahaan LQ-45 sebagai sampel penelitian

27

Jumlah data pengambilan sampel (27x 3

tahun)

Data outlier

81

Jumlah data yang diolah

Sumber: Data diolah

\section{Statistik Deskriptif}

Tabel 2.Statistik Deskriptif

\begin{tabular}{lccccc}
\hline Variabel & $\mathrm{N}$ & Min & Max & Mean & Std. Dev \\
\hline LEV & 73 & 0.18 & 11.30 & 2.1859 & 2.55693 \\
LIK & 73 & 0.28 & 5.63 & 1.9649 & 1.28127 \\
UP & 73 & 12.20 & 22.63 & 18.2327 & 2.02564 \\
DKI & 73 & 0.13 & 0.80 & 0.4090 & 0.13620 \\
KA & 73 & 0.69 & 2.08 & 1.3122 & 0.29364 \\
KK & 73 & 0.00 & 0.36 & 0.0901 & 0.08013 \\
\hline
\end{tabular}

Sumber: Data diolah

Berdasarakan hasil pengujian pada tabel 2 dilakukan analisis deskriptif kinerja keuangan dengan nilai minimal 0.00 , nilai maksimal 0.36 , nilai rata-rata 0.0901, dan standar deviasi 0.08013. Nilai minimal varaiabel leverage 0.18 , nilai maksimal 11.30 , nilai ratarata 2.1859, dan standar deviasi 2.55693. Nilai minimal variabel likuiditas adalah 0.28 , nilai maksimal 5.63, nilai rata-rata 1.9649 , dan standar deviasi 1.28127 . nilai minimal variabel ukuran perusahaan adalah 12.20 , nilai maksimal 22.63, nilai rata-rata 18.2327 , dan standar deviasi 2.02564. Nilai minimal varaiabel dewan komisaris indepnnden adalah 0.13 , nilai maksimal 0.80 , nilai rata-rata 0.4090 dan standar deviasi 0.13620 . nilai minimal variabel komite audit adalah 0.69 dan nilai maksimal 2.08, nilai rata-rata 1.3122 dengan nilai standar deviasinya 0.29364 .

\section{Uji Asumsi Klasik}

Tabel 3. Normalitas

\begin{tabular}{cccl}
\hline $\begin{array}{c}\text { Kolmogorov- } \\
\text { Sminov Z }\end{array}$ & Asymp.Sig. & Standar & Keputusan \\
\hline 1.356 & 0.051 & $>0.05$ & Normal \\
\hline
\end{tabular}

Sumber: Data diolah

Berdasarkan pengujian normalitas pada tabel 3 diatas diperoleh nilai signifikansi $0.051>(0.05)$. Maka, dapat disimpulkan data residual model regresi dalam penelitian berdistribusi normal.

Tabel 4. Multikolinearitas

\begin{tabular}{lcccc}
\hline Variabel & Tolerance & Std & VIF & Keterangan \\
\hline LEV & 0.477 & $>0.10$ & 2.096 & \\
LIK & 0.674 & $>0.10$ & 1.484 & Bebas \\
UP & 0.710 & $>0.10$ & 1.408 & multikolinearitas \\
DKI & 0.763 & $>0.10$ & 1.310 & \\
KA & 0.794 & $>0.10$ & 1.259 & \\
\hline
\end{tabular}

Sumber: Data diolah
Berdasarkan pengujian dapat dilihat bahwa tidak terdapat varaiabel bebas dengan nilai toleransi $<0.10$ berati tidak ada hubungan linear antar variabel independen. Hasil perhitungan variance inflation factor (VIF) juga menunjukkan hasil yang sama, yaitu tidak terdapat varaiabel independen dengan $<10$, sehingga dapat disimpulkan bebas multikolinearitas.

Tabel 5. Autokolerasi

\begin{tabular}{|c|c|c|c|}
\hline Nilai Z & Asymp. Sig. & Standar & Keputusan \\
\hline-1.295 & 0.195 & $>0,05$ & Bebas autokorelasi \\
\hline
\end{tabular}

Melalui hasil pengujian run test pada tabel 5 nilai sig. > 0.05. Hasil tersebut dapat disimpulkan bahwa bebas autokolerasi

Tabel 6. Heteroskedastisitas

\begin{tabular}{lllc}
\hline Variabel & Sig. & Standar & Keterangan \\
\hline LEV & 0.918 & $>0.05$ & \\
LIK & 0.270 & $>0.05$ & Bebas \\
UP & 0.591 & $>0.05$ & heterokedastisitas \\
DKI & 0.405 & $>0.05$ & \\
KA & 0.666 & $>0.05$ & \\
\hline
\end{tabular}

Sumber: Data diolah

Berdasarkan hasil perhitungan dan model regresi pada tabel 6 diatas menunjukkan nilai signifikan dari varaiabel seperti leverage, likuiditas, ukuran perusahaan, dewan komisaris independen serta komite audit $>0.05$. dapat disimpulkan bahwa bebas heteroskedastisitas.

\section{Uji Regresi Linear Berganda}

Tabel 7. Regresi Berganda

\begin{tabular}{lc}
\hline Model & Unstandardized Coefficients \\
& B \\
\hline (Constant) & -0.007 \\
LEV & -0.013 \\
LIK & 0.030 \\
UP & -0.001 \\
DKI & -0.240 \\
KA & -0.004 \\
\hline
\end{tabular}

Sumber: Data diolah

Dalam penelitian ini digunakan model persamaan regresi linear berganda, yaitu sebagai berikut:

$\mathrm{KK}=-0.007-0.013(\mathrm{LEV})+0.0302(\mathrm{LIK})-0.001(\mathrm{UP})-$ $0.240(\mathrm{DKI})-0.004(\mathrm{KA})$

Keterangan:

KK : Kinerja Keuangan

LEV : Leverage

LIK : Likuiditas

DKI : Dewan Komisaris Independen

KA : Komite Audit 
a. Nilai konstanta 0.007 dengan parameter negatif berati jika variabel leverage, likuiditas ukuran perusahaan, dewan komisaris independen dan komite audit konstan atau sama dengan nol maka nilai kinerja keuangan adalah -0.07 .

b. Nilai koefisien regresi variable leverage dengan parameter negatif adalah 0.013. hal ini dapat dijelaskan bahwa setiap kenaikan rasio leverage akan menurunkan kinerja keuangan, atau dapat dijelaskan bahwa apabila variabel rasio leverage meningkat $1 \%$ dengan asumsi variabel lain tidak mengalami perubahan maka rasio leverage akan turun sebesar 0.013 .

c. Nilai koefisien regresi variabel Likuiditas dengan parameter positif sebesar 0.030. artinya setiap kenaikan nilai likuiditas akan meningkatkan kinerja keuangan dan menigkatkan kinerja keuangan, atau jika varaiabel lain diamsusikan tetap, jika variabel lukuiditas meningkat sebesar $1 \%$, maka kinerja keunagn akan meningkat sebesar 0.030

d. Nilai koefisien regresi variabel ukuran perusahaan dengan parameter negatif adalah 0.001 . artinya setiap kali nilai ukuran perusahaan bertambah maka akann menurunkan kinejra keuangan, atau dapat dijelaskan bahwa jika variabael lain tetap tidak berubah dan ukuran perushaan bertambah sebesar 1\%maka kinerja keuangan akan tururn sebesar 0.001

e. Nilai koefisien regresi variable dewan komisaris independen dengan parameter positif sebesar 0.240. artinya setiap kenaikan nilai dewan komisaris independen akan meningkatakn kierja keuangan, atau dapat diartikan dewan komisaris independen meningkat sebesar $1 \%$ dengan asumsi variabel lain tetap yaitu kinerja keuangan. akan meningkat sesuai 0.240

f. Nilai koefisien regresi variabel komite audit dengan parameter negatif sebesar 0.004. artinya setiap kenaikan nilai komite audit akan menurunkan kinerja keuangan, atau dapat diamsusukan jika variabel lain tetap, jika komite audit meningkat sebesar 1\%, maka kinerja keuangan menurun 0.004 .

\section{Kelayakan Model (Uji F)}

Tabel 8 Kelayakan Model

\begin{tabular}{cccccc}
\hline Model & $\mathrm{F}_{\text {hitung }}$ & $\mathrm{F}_{\text {tabel }}$ & $\mathrm{Sig}$ & Ketentuan & Kesimpulan \\
\hline 1 & 18.114 & 2.352 & 0.000 & $<0,05$ & Model Layak \\
\hline
\end{tabular}

Sumber: Data diolah

Berdasarkan tabel uji $\mathrm{F}$ diatas diperoleh nilai $\mathrm{F}_{\text {hitung }}$ sebsar 6.571 dengan nilai signifikansi $0.00<\alpha=0,05$. Hasil menunjukkan model penelitian adalah fit atau ada pengaruh secara keseluruhan yang signifikan antara (leverage, likuiditas, ukuran perusahaan, dewan komisaris independen, serta komite audit) terhadap kinerja keuangan.

\section{Uji Hipotesis (t)}

Tabel 9. Hipotesis

\begin{tabular}{lccccl}
\hline Hipotesis & $\mathrm{t}_{\text {hitung }}$ & $\mathrm{t}_{\text {tabel }}$ & Sig. & Kriteria & Kesimpulan \\
\hline (LEV) H1 & -3.648 & -1.996 & 0.001 & 0,05 & Diterima \\
(LIK) H2 & 4.914 & 1.996 & 0.000 & 0,05 & Diterima \\
(UP) H3 & -0.372 & -1.996 & 0.711 & 0,05 & Ditolak \\
(DKI) H4 & 4.473 & 1.996 & 0.000 & 0,05 & Diterima \\
(KA) H5 & -0.162 & -1.996 & 0.872 & 0,05 & Ditolak \\
\hline
\end{tabular}

Sumber: Data diolah

Penelitian ini menggunakan 5 (lima) hipotesis yang diuji untuk memahami pengaruh levarege, likuiditas, ukuran perusahaan, dewan komisaris independen, dan komite audit. Beerdasarkan tabel 9 diatas, maka hasil pengujian hipotesis untuk masingmasing variabel independen pada varaiabel dependen akan diintrepetasikan sebagai berikut :

\section{Leverage terhadap kinerja keuangan}

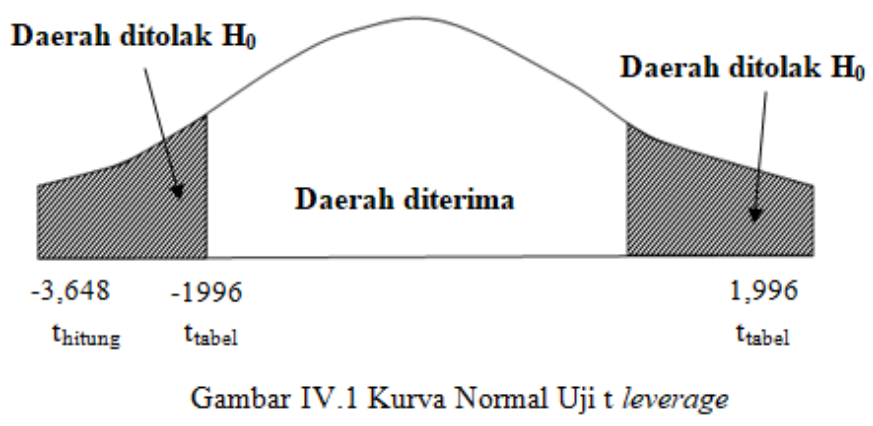

Hasil uji t variabel leverage menunjukkan thitung $-3.648<$ ttabel -1.996 dan nilai signifikansi $0.001<0.05$, sehingga Ho ditolak dan $\mathrm{H}_{\mathrm{a}}$ diterima.

\section{Likuiditas terhadap kinerja keuangan}

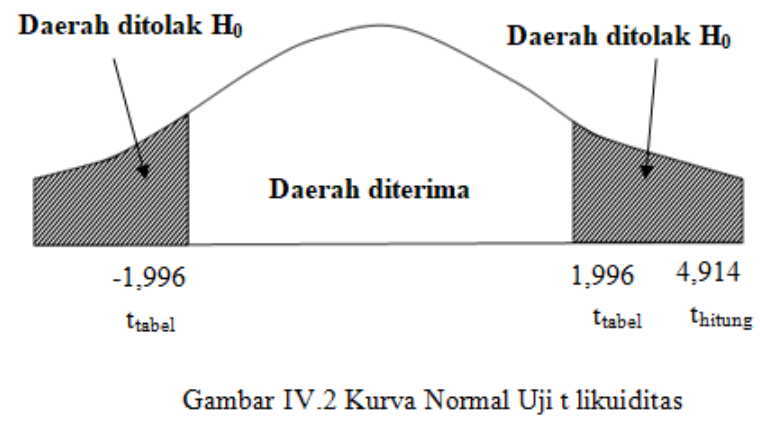

Hasil uji t variabel likuiditas menunjukkan thitung 4.914> ttabel 1.996 dan nilai signifikansi $0.000<0.05$, sehingga $\mathrm{Ho}$ ditolak dan $\mathrm{H}_{\mathrm{a}}$ diterima. 
Masna Rina Fitriyati, Kartika Hendra Titisari dan Yuli Chomsatu Samrotun, Kinerja Keuangan Ditinjau Dari Leverage, Likuiditas, Ukuran Perusahaan, Dewan Komisaris Independen, Dan Komite Audit

\section{Ukuran perusahaan terhadap kinerja keuangan}

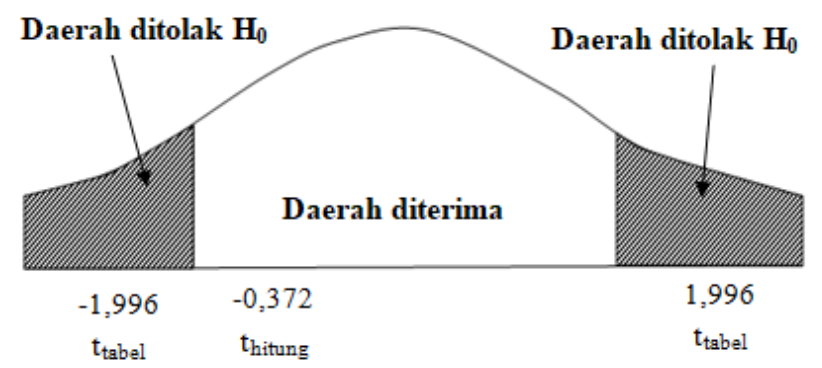

Gambar IV.1 Kurva Normal Uji t ukuran perusahaan

Hasil uji $t$ variabel ukuran perusahaan menunjukkan thitung -0.372> ttabel -1.996 dan nilai signifikansi $0.711>0.05$, sehingga $\mathrm{Ho}$ diterima $\mathrm{H}_{\mathrm{a}}$ ditolak

\section{Dewan kimisaris independen berpegaruh terhadap kinerja keuangan}

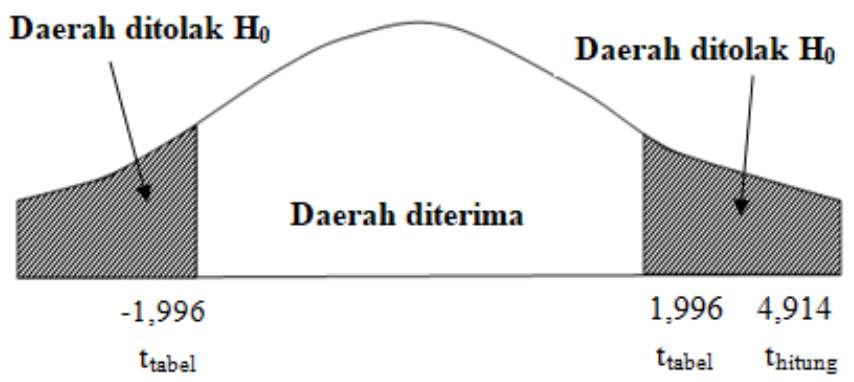

Gambar IV.2 Kurva Normal Uji t Dewan Komisaris Independen.

Hasi uji t untuk dewan komisaris independen menunjukkan thitung 4.473> ttabel 1.996 dan nilai signifikansi $0,000<0.05$, sehingga Ho ditolak dan $\mathrm{H}_{\mathrm{a}}$ diterima.

\section{Komite audit tidak berpengaruh terhadap kinerja keuangan}

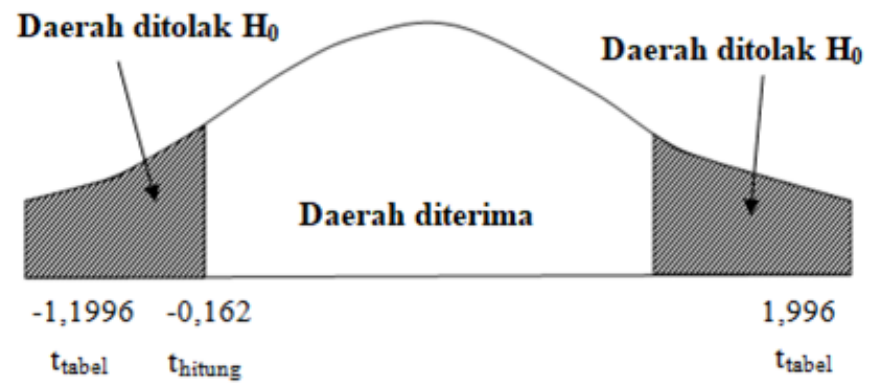

Gambar IV.5 Kurva Normal Uji t komite audit

Hasil uji t untuk komite aduit menunjukkan thitung sebesar $-0,162>$ ttabel -1.996 dan nilai signifikansi $0,329>0,05$, sehingga Ho diterima dan $\mathrm{H}_{\mathrm{a}}$ ditolak.

Tabel 10. Koefisien Detereminasi

\begin{tabular}{ccl}
\hline \multicolumn{2}{c}{ Model Adjusted $r$ square } & \multicolumn{1}{c}{ Kesimpulan } \\
\hline & & $\begin{array}{l}\text { Variabel leverage, likuiditas ukuran } \\
\text { perusahaan, dewan komisaris } \\
1\end{array}$ \\
& & $\begin{array}{l}\text { independen, komite audit memiliki } \\
\text { pengaruh sebesar } 54.3 \% \text { terhadap } \\
\text { kinerja keuangan. }\end{array}$ \\
\hline
\end{tabular}

Sumber: Data diolah

Nilai adjusted $r$ square diperoleh Sri pwngujian menggunakan koefisin diterminasi sebesar 0.543 (54.3\%) yang berati variabel kinerja keuangan dapat dijelaskan variabel leverage, likuiditas, ukuran perusahaan, dewan komisaris independen, dan komite audit. Sementara $45.7 \%$ dari sisa kinerja keuangan dapat dijelaskan varaibel lain yang tidak termasuk dalam model penelitian.

\section{Pembahasan}

\section{Pengaruh leverage terhadap kinerja keuangan}

Berdasarkan pada tabel 9, diperoleh hasil leverage berpengaruh terhadap kinerja keuangan perusahaan LQ45. Leverage menunjuk pada penggunaan aset serta sumber modal oleh perusahaan dengan biaya tetap untuk meningkatkan potensi keuntungan pemegang saham. Menurut Aiman \& Rahayu (2019), dengan tingginya leverage maka semakin tinggi kinerja keuangannya. Rasio hutang terhadap ekuitas akan mempengaruhi kinerja perusahaan karena perusahaan akan cenderung banyak memakai hutang untuk dana usaha sebagai sumber penambahan modal usaha. Hal ini sejalan dengan Kajola et al. (2019) dan Tasmil et al. (2019) menyatakan leverage mempengaruhi kinerja keuangan.

\section{Pengaruh likuiditas terhadap kinerja keuangan}

Berdasarkan tabel 9 menunjukkan likuiditas berpengaruh tehadap kinerja keuangan perusahaan LQ45. Likuiditas adalah kemmapuan perusahaan dalam menyediakan dana untuk operasioanal perusahaan dan mencukupi kewajiban jangka pendeknya. Lukuiditas dihitung dengan menggunakan current ratio, semakin besar rasio aktiva lancar terhadap kewajiban lancar maka semakin tinggi kemampuan perusahaan dalam membayar hutang jangka pendeknya. Sebaliknya, current ratio yang begitu tinggi justru kurang baik karena mengindikasikan adanya dana menganggur yang besar pada akhirnya akan menurunkan kapasitas perusahaan. Hasil penelitian ini sejalan dengan Putri \& Dermawan (2020) dan Maryadi \& Darmawan (2019) yang menunjukkan hasil likuditas mempengaruhi kinerja keuangan.

\section{Ukuran perusahaan terhadap kinerja keuangan}

Berdasarkan hasil pengujian pada tabel 9 menunjukkan ukuran perusahaan tidak mempengaruhi 
kinerja keuangan perusahaan LQ-45. Ukuran perusahaan yang diukur dengan $\ln$ (total asset) tidak dapat menentukan kinerja keuangan perusahaan yanag baik. semakin besar aset perusahaan maka semakin rumit pula masalah keagenan yang dihadapi perusahan, yang akan meningkatkan biaya operasional perusahaan dan menurunkan laba perusahaan. Dapat disimpulkan kinerja keuangan tidak dipengaruhi oleh ukuran perusahaan. Hal ini sejalan Sari et al. (2020) dan Eyigege (2018) menunjukkan ukuran perusahaan tidak mempengaruhi kinerja keuangan.

\section{Dewan komisaris independen terhadap kinerja keuangan}

Berdasarkan hasil pengujian pada tabel 9, diperoleh hasil dewan komisaris independen mempengaruhi kinerja keuangan perusahaan LQ-45. Dewan komisaris independen dapat mendorong perusahaan untuk meningkatkan kinerja keuangan. semakin banyak jumlah dewan komisaris independen maka semakain mudah mengontrol dan memantau aktivitas perusahaan. Dewan komisaris dapat membantu perusahaan terhindar dari anacaman eksternal, sehingga dapat menjaga sumber daya perusahaan untuk memperoleh lebih banyak keuntungan yang mampu meningkatkan kinerja keuangan perusahaan. Penelitian ini sejalan dengan Corrina (2018) dan Fuad (2018) menunjukkan dewan komisaris independen mempengaruhi kinerja keuangan.

\section{Komite audit terhadap kinerja keuangan}

Berdasarkan hasil pengujian pada tabel 9, terlihat komite audit tidak mempengaruhi kinerja keuangan LQ45. Jumlah komite audit tidak dapat semata-mata didasarkan pada kepatuhan terhadap regulasi yang mewajibkan perusahaan membentuk koite audit untuk memastikan efektivitas komite dalam memantau kinerja perusahaan. Komite audit hanya membantu manajemen memantau proses pelaporan keuangan, namun hasil tersebut ditentukan oleh dewan direksi, sehingga komite aduit perusahaan tidak mempengaruhi kinerja keuangan. Hal ini sejalan dengan penelitian Sembiring dan Saragih, (2019), Pratiwi dan Khuzaini, (2018) menunjukkan komite audit tidak mempengaruhi kinerja keuangan.

\section{SIMPULAN}

Penelitian ini bertujuan untuk menguji serta menganalisa pengaruh leverage, likuiditas, ukuran perusahaan, dewan komisaris independen, serta komite audit pada kinerja keuangan. Pemilihan sampel menggunakan metode purposive sampling, sehingga diperoleh 27 perusahaan LQ-45 yang terdaftar di Bursa Efek Indonesia tahun 2017-2019. Alat analisia menggunakan analisis regresi linear berganda. Berdasarkan hasil analisa (uji t) menunjukkan (leverage, likuiditas, serta dewan komisaris independen) mempengaruhi kinerja keuangan. sedangan, (ukuran perusahaan dan komite aduit) tidak mempengaruhi kinerja keuangan.

\section{DAFTAR PUSTAKA}

Ai Aiman, R., \& Rahayu, S. (2019). Pengaruh Good Corporate Governance , Leverage Terhadap Kinerja Keuangan ( Studi Kasus Pada Bank Umum Swasta Nasional dan Bank Usaha Milik Negara yang Terdaftar di Bursa Efek Indonesia Tahun 2014-2017 ). E-Proceeding of Management, 6(2), 3190-3199.

Anthonie, D. P., Tulung, J. E., Tasik, H. H. D., Manajemen, J., Sam, U., \& Manado, R. (2018). Pengaruh Struktur Modal Terhadap Kinerja Keuangan Pada Perbankan Yang Terdaftar Di Bursa Efek Indonesia Periode 2012-2016. Jurnal EMBA: Jurnal Riset Ekonomi, Manajemen, Bisnis Dan Akuntansi, 6(2), 610-619.

Azzahra, A. S., \& Nasib. (2019). Pengaruh Firm Size Dan Leverage Ratio Terhadap Kinerja Keuangan pada Perusahaan Pertambangan. Jwem Stie Mikroskil, 9 (April), 13-20.

Corrina, F. (2018). Pengaruh Komisaris Independen Dan Komite Audit Terhadap Kinerja Keuangan Perusahaan Manufaktur Yang Terdaftar Di Bursa Efek Indonesia (Bei) Pada Tahun 2015 - 2017. Jurnal Manajemen Dan Bisnis, 7(4), 137-142.

Eyigege, A. I. (2018). Influence of Firm Size on Financial Performance of Deposit Money Banks Quoted on the Nigeria Stock Exchange. International Journal of Economics and Financial Research ISSN, 4(9), 297-302.

Kajola, S. O., Alao, A., Sanyaolu, W. A., \& Ojurongbe, O. J. (2019). Effect of liquidity and leverage on firm financial performance of Nigerian listed consumer goods firms. The Journal of Contemporary Economy, 4(3), 91-101.

Mwangi, M. (2018). The Effect of Size on Financial Performance of Commercial Banks in Kenya. European Scientific Journal, ESJ, 14(7), 373.

Pratiwi, A. D., \& Khuzaini. (2018). Pengaruh Good Corporate Governance dan Kepemilikan Manajerial terhadap Kinerja Keuangan Perusahaan Perbankan di BEI. Jurnal Ilmu Dan Riset Manajemen, 7(3), 1-18.

Putri, M. C., \& Dermawan, E. S. (2020). Faktor-Faktor yang Mempengaruhi Kinerja Keuangan Pada Perusahaan Manufaktur. 2(1), 469-477.

Rahmawati, I.A., Rikumahu, Brady., dan Dillak, V. J. (2017). Pengaruh dewan direksi, dewan komisaris, komite audit dan Corporate social responsibility Terhadap kinerja keuangan perusahaan. Jurnal Akuntansi Dan Ekonomi, 2(2), 54-70.

Sari, T. D., Titisari, K. H., \& Nurlaela, S. (2020). Pengaruh Kepemilikan Manajerial, Komite Audit, Leverage Dan Ukuran Perusahaan Terhadap Kinerja Keuangan. 4(1), 15-26. 
Sembiring, C. Y. B., \& Saragih, A. E. (2019). Pengaruh Komisaris Independen dan Komite Audit Terhadap Kinerja Keuangan Terdaftar Di Bursa Efek Indonesia. Jrak, 5(2), 229-242.

Shibutse, R. L., Kalunda, E., \& Achoki, G. (2019). Effect of leverage and firm size on financial performance of deposit taking savings and credit cooperatives in Kenya. International Journal of Research in Business and Social Science (21474478), 8(5), 182-193.

Situmorang, C. V., \& Simanjuntak, A. (2019). Pengaruh Good Corporate Governance Terhadap Kinerja Keuangan Perusahaan Perbankan Yang Terdaftar Di Bursa Efek Indonesia Tahun 2013-2016. JURNAL AKUNTANSI DAN BISNIS : Jurnal Program Studi Akuntansi, 5(2), 160.

Sunardi, N., \& Sasmita, A. S. (2019). Pengaruh Likuiditas, Leverage Dan Growth Terhadap Kinerja Industri Makanan Dan Minuman Yang Tercatat Di Indonesia Stock Exchange Selama Periode Tahun 2011 - 2015. Jurnal SEKURITAS (Saham, Ekonomi, Keuangan Dan Investasi), 2(2),

Tasmil, L. J., Malau, N., \& Nasution, M. (2019). Pengaruh Pertumbuhan Penjualan, Current Ratio, Debt to Equity Ratio terhadap Kinerja Keuangan PT.Sirma Pratama Nusa Periode 2014-2017. Jesya (Jurnal Ekonomi \& Ekonomi Syariah), 2(2), 131139. 